\title{
Potentialities of Shared Management for a Sustainable Society
}

\author{
Renato de Oliveira Brito ${ }^{1}$ \\ Luiz Síveres ${ }^{2}$
}

\begin{abstract}
The aim of this study was to outline the factors that contribute to a feeling of motivation on the part of the school community and to encouragement of its participation in issues related to the school routine. We specifically sought to understand whether the management framework adopted by the school, the object of this study, contributes to the active participation of the community to facilitate the implementation of projects related to environmental education for a sustainable society. The methodology of this qualitative research was a review of the literature and application of questionnaires as data collection instruments. We concluded that the factors that contribute to the school community participating in the elaboration and implementation of the educational policy project of the school, the object of this study, lead to its shared management model favoring the implementation of educational projects for a sustainable society.
\end{abstract}

Keywords: Shared management. Environmental Education. School and community relationship.

\section{Introduction}

The participation of the school community in the administrative and pedagogical processes of successful schools has stood out as an important tool for achieving good results at the same time that demand grows for a society that adopts sustainable practices of development. This scenario leads to the consideration that sustainability, with the school as the basic element for spreading this information, is structured on three basic foundations: shared management, environmental education and sustainable society. The logic established through the relationship of these three foundational elements in the school is that shared management allows environmental education to be applied and disseminated in the most effective way, which promotes a sustainable society. Thus, the theme of this study is shared management as the element which facilitates implementation of environmental education projects for constructing a sustainable society.

We seek, then, to carry out a study of the acts of participation of the school community that may assist in the development of environmental education projects. In

${ }^{1}$ Visiting Researcher at the Centre For Social Science Research, University of Cape Town - South Africa (2005), Consultant / Evaluator projects of the Ministry of Education - MEC and the UNDP - United Nations (2008-2011) and Student/Researcher of the Doctoral Program in Education at the Catholic University of Brasilia. Nowadays he is Head of Environmental Sustainability on the Brazilian Government. 2 Post Doctoral Degree in Education on Pontifical Catholic University of São Paulo (PUC-SP) and PHD in Sustainable Development (University of Brasilia), Consultant in Education Field and. Nowadays he is a Director/ Professor of Master's and Doctorate Education Program of the Catholic University of Brasilia. 
this context, two questions directed the research - first, to understand what motivates the members of the school community to participate; and, secondly, to determine if the school provides opportunities that value this participation and which may become elements that favor the implementation of projects directed toward education for sustainability. Thus, the challenge of this study is to understand and indicate the importance of shared management when it incorporates environmental education for promoting a sustainable society.

The methodology used in this study was research of a qualitative approach with field study and application of questionnaires. The school chosen as the object of case study for this research is a public school located in the Distrito Federal, Brazil, and it was chosen as a successful model of good educational results achieved through the implementation of shared management. The purpose of this study was to outline the elements or factors that contribute to a feeling of motivation on the part of the school community and to encouragement of its participation in issues related to the day-to-day school routine, and to identify the actions which favor the effective participation of the community in the school under study, seeking to analyze if the shared management model implemented in the school, the object of study, is adequate for the development of educational projects for sustainability.

In regard to organization, this article is divided into seven items, the first being this introduction. In the two subsequent items, a review of the specialized literature regarding shared management in the school and the relationship between it and environmental education are presented. There is a specific item in respect to shared management in the educational policy project (projeto político pedagógico - PPP) of the school under study and, subsequently, the methodology used in the study, the analysis of data and final considerations are presented.

\section{Shared Management in the School}

Democratic management requires a redefinition of power relations within the school organization with a view toward overcoming the current model; by means of this democratic management, school officials are no longer the only ones to make decisions, and sharing of responsibilities arises. This is because educational work consists of activity of a collective nature, the success of which presupposes, according to Lück et al (2010), the participation and effective integration of all the agents that belong to the school community.

It is important to recognize that whenever society comes across situations of change in its structure, new demands are made on the school since the presuppositions of education for citizenship that society comes to require are altered. For that reason, Penin e Vieira (2002) urge the school to remain attentive and flexible to the changes that are inherent to historical periods. Thus, flexibility constitutes a great challenge for school management that is guided by democratic principles, as reinforced by the words of Hora:

The need for promoting coordinated action between the school and the community it serves is fundamental. The understanding that the school is not a body isolated from the global context of which it is a part must be present in the process of organization such that the actions to be developed are directed to community needs [...] In this sense, it is 
necessary to understand the conceptions of community and the relationships that the school establishes with its immediate social context (2009, p. 59).

For this study, we intend to collect and analyze data that allow understanding of the relationship that exists between environmental education and shared educational management, considering the latter as a microcosm of the socio environmental governance which is established within the school.

More generally, management may be understood as the administrative practice that defines and directs the use of financial, material, information, technological, human, and partnership resources, as well as the policies and alliances for achieving goals (COSTA, 2007). The elements of participation and of human interactions are intrinsic to management, as may be observed in the concept elaborated by Lück (2009, p. 21), according to which management may be understood as "a process of mobilization of the competence and energy of collectively organized people so that, through their active and competent participation, they most fully promote the attainment of the goals of their work unit, in this case, educational goals".

The management concept itself presented by the authors points to the idea that this occurs through the integration and interaction of people focused on a determined goal. Shared management is therefore the process of making decisions and elaboration and implementation of planning which occurs together with the participation of the agents affected by the results of an organization. It is also associated with the strengthening of democratization of the pedagogical process as of the moment at which all those that are affected by the educational process come to be recognized as legitimate parties to intervene in the process of constructing the school educational project. It functions through the creation of formal and informal spaces which facilitate responsible participation of the entire school community in the policy and pedagogical decisions, and its purpose is directed to the contribution that participation offers as a necessary and indispensable instrument for attaining positive results in the school (SANTOS, 2008).

\section{The Relation of Shared Management and Environmental Education}

Education is a basic tool for social and economic development and the greater the number of agents involved and committed to its process of formulation and implementation, the more effective its action becomes. In the face of this reality, and based on the premise that education constitutes an indispensable element for sustainable development, the following research problem arises: what are the strategies adopted by shared management that favor the implementation of a successful model of environmental education?

It is expected that research may help in understanding shared management, and how the action of the most diverse social agents within the school contributes to the formulation of a successful model of environmental education, contributing to sustainable development.

Sachs (1992) considers that there is an intermediate route between sounding the alarm in respect to running out of natural resources and optimism in respect to the belief that technology is a solution. Within this scenario, education becomes a driving force for sustainable development. Upon discussing this theme, Síveres (2010) states that education alone, in an isolated way, is not capable of promoting sustainable 
development, but that it is a fundamental tool for equality of access to opportunities for quality of life for all and also for development of social and environmental awareness. Thus, it is capable of generating actions that collaborate with the development and continuity of a sustainable society where government entities, private initiative and organized civil society unite around the concept of sustainability, creating a governance structure where knowledge and action are complementary and generate forms of social and economic growth aligned with the need for preserving and caring for the environment.

Therefore, environmental education arises as an important tool for the construction of rational production models that may promote sustainable development. It is considered that environmental education must be promoted under an interdisciplinary pedagogical and methodological model for it is observed that "although there was the development of environmental knowledge in various themes of the natural and social sciences, this knowledge was not fully incorporated in the curricular contents of new educational programs" (LEFF, 2001, p. 241).

Legislation on environmental education policy in Brazil was instituted by Law no. 9.795/1999 and by decree no. 4.281/2002. According to this legislation, environmental education consists of processes through which individuals and the collectivity construct social values, knowledge and skills directed to environmental conservation; all have the right to environmental education and this must be an essential and permanent component of the educational system.

According to legislation, environmental education must occur in both the formal and informal dimensions of education, and must be present in the curriculum at all levels of formal education, both in public and private institutions. Furthermore, according to legislation, there must be incentive for environmental education to occur with individual and collective participation, this being an exercise of citizenship where partnerships between public and private institutions should be encouraged and promoted with a view toward sensitizing collective society in regard to environmental issues (Law no. 9.795/1999 and Decree no. 4.281/2002).

It is possible to make environmental education the common theme of the process of transition to a sustainable society. However, for this to occur, it is necessary to join education and environmental ethics, building a new educational model where "the environmental principles and values promoted through a pedagogy of complexity" (LEFF, 2001, p. 243) lead the student to perceive the interrelations that exist between his own development and the reality of the social, economic and environmental milieu that surrounds him, which confers a subjective feature to knowledge.

That requires an educational model that is only possible from the interdisciplinarity of environmental education. Thus, it may be affirmed that the unity between shared management and environmental education should happen "within a strategic process that encourages collective reconstruction and subjective re-appropriation of knowledge" (LEFF, 2001, p. 246); only that way is it possible to achieve the stage of development necessary for constructing a sustainable society.

Environmental education must be worked on within an interdisciplinary perspective, composing a set of learning objectives for the development of a sustainable society, leading to integration of this theme, which will run through the series of school subjects and pedagogical experiences. Corroborating this proposal, Soares (2008) affirms that the relationship between education and sustainable development becomes stronger on site, 
with the interaction of the entire community. In the same vein, Weller e Pfaff (2010) draw a relationship between education and shared management when they analyze that of the seven strategies proposed by the Decade of Education for Sustainable Development, three of them are directly connected to a participative model of education:

i. $\quad$ social mobilization and establishment of prospects;

ii. consultation and accountability;

iii. partnership and networks;

iv. empowerment and training;

v. research and innovation;

vi. information and communication technologies;

vii. monitoring and evaluation.

Based on this proposal, there is the need for reformulation of the practices and methodologies used in education so that education is more aligned to contribute to the foundations of structuring sustainable development, for teaching may no longer be directed solely to a manner of transmitting knowledge, but rather create an approach in which teachers and students work together to acquire knowledge and migrate to the practice of participation in the decision-making process. Thus, students participate in the decisions regarding the way they should learn, at the same time in which learning may occur in an understandable language, drawing it nearer to the personal and professional day-to-day life of the student.

It is important that the educational process also be relevant locally, in other words, that it relate to the overall local happenings that have an effect on the life of the student and also of the community in which the student and the school lie. This requires that the concept and practices of sustainable development be adapted to the local culture and reality (WELLER e PFAFF, 2010).

Within these considerations, shared management becomes a conditioning factor for education aligned with sustainable development, for environmental issues brought to social awareness have made ecological principles come to be discussed within the most diverse types of scientific subjects. Thus, an age of environmental knowledge permeated by the most diverse sciences has been ushered in.

Therefore, "the environmental problematic has led to the transformation of the theoretical and practical knowledge on which the dominant social and productive rationality is based" (LEFF, 2002, p. 161). Thus, the economic, scientific and technological rationality of modernity is aligned with the need for joining the most diverse branches of science for the purpose of elaborating integrated projects that may allow a logic of production capable of promoting sustainable development.

\section{Shared Management as a Pedagogical Policy}

The educational policy project (PPP) of the school is planning that presents all the strategies and objectives that will be followed by the school in order to achieve its mission of educating and forming citizens in the best way possible. Thus, all the pedagogical directives of the school are defined in it. In a shared management model, the manager directs the application of this document, which is formulated and implemented with the aid of the entire school community. 
We observe that in the first part, the PPP of the school which is the object of this study was concerned with explaining the creation of the PPP and the manner that it would be applied. It presented the purpose of this Project and defined the results to be achieved. The school gives priority to meeting the needs that the community presents - an example of this is Youth and Adult Education (Educação de Jovens e Adultos - EJA 1st and 2 nd phases), which was implemented in the school due to community demand. In addition, the school has a listing of multidisciplinary projects, all undertaken with the participation and encouragement of the community. Some were given awards of recognition, both for the school and for individual students. The PPP itself highlights the publication of a book written by the 1 st grade students whose main theme is the environment, specifically the conservation of a park located in proximity to the community. The book, published in 2004 and entitled "Sucupira Park is Ours", had a printing of 800 copies. Other projects listed in the PPP make reference to partnerships with public and private institutions and to the participation of the school in festive and competitive events, as a way of highlighting their importance within that community. Participative management is present in the PPP of the school, as may be seen in the following objectives which were presented for 2010 in the school:

A. Encourage lectures, workshops, dinners and fairs to promote the social integration of those active in the school and consequently bolster improvement of selfesteem of students, teachers, service workers and the general community institutionally connected to this school;

B. Creation of specific dates for the participation of the entire community in the school environment, with activities like lectures, workshops, games, diverse artistic and cultural displays and activities which meet the criteria of the Education for Life Week (Semana de Educação para a Vida);

C. Invite the community to greater presence in school decisions so as to strengthen institutions like the APM (Parent-Teacher Association) and School Council/Security and Promotion of Peace;

D. Organize a preliminary agenda with the school segments to define the matters to be dealt with in meetings;

E. Create opportunities for at least three events that contribute to qualitative improvement of the self-esteem of students, teachers and service workers;

The PPP of the school dedicates a specific item to the presentation of shared management, and then presents diverse projects and actions directed to sharing of responsibilities with the community in its objectives for the year 2011, such as:

A. Rendering of accounts of the resources and benefits obtained during the school semester to the diverse segments of the school;

B. Search for partnerships, with mobilization of local businesses for the needs of the school by means of visits, and invitations for getting to know the facilities and the realities of the pedagogical/administrative work of the Teaching Unit;

C. Refinement of the Count on Me Project (Projeto Conte Comigo), a human resource bank of the school composed of people of the community that may make their abilities available for carrying out small repairs in the school; 
D. Carrying out events like festivals, drawings and bingos to raise funds for the teaching unit;

E. Rendering of accounts every two months to the entire school community regarding revenues and expenses of the resources managed by the APM, in the parentteacher meetings;

F. Search for partnerships, governmental resources or otherwise, for the purpose of carrying out remodeling of the playground and bathrooms of the teaching unit in question;

G. Holding systematic meetings every two months with the School Council for the purpose of defining the use of financial resources directed to the School.

\section{Indicators of the route taken}

The route taken by this study especially counted on the assistance of the stakeholders of the educational institution (parents, students, teachers and employees) who contributed to the proposed reflection. For that reason, the option was made to collect data for this study with a qualitative approach through a review of the literature, and field work with a semi-structured interview. Thus, the documentary sources of the study were reports, journal articles, magazine articles, academic articles and books. And, in relation to the interviews, the questions presented in table 1 were raised.

Table 1 - List of questions of the semi-structured interview.

Source: Prepared in research.

1. As part of the school community, at what times are you called on to participate?

2. In which actions, projects and activities do you participate in the school?

3. What motivates you to participate in the school community?

4. Does the school provide opportunities that value your participation?

5. What are the benefits for this school in following a Shared Management model?

6. Does your participation strengthen the Shared Management model taken on by this school?

Data collection also included the educational policy project (PPP) of the school under study. This document, whose main points were presented in item 4, helped in contextualization of this case study through presenting important information for understanding how the community drew near to its own history and the school. This information served as a basis for a comparative study of the reality experienced before implementation of this management model and that which was achieved after implementation, checking if the new shared management model creates an adequate environment for environmental education for promotion of a sustainable society.

Based on this premise, a research study was prepared with two basic questions which were applied to both teachers and parents of students of the school which is the object of this study. All of this focused on verification of the essential features for implementation of a successful shared management model and its contribution to environmental education with a view toward a sustainable society. 
In the field work, it was seen that the school which was the object of this study did not offer resistance to the shared management model. According to the reports collected, we have the impression that the community had already felt a pressing need for sharing between the school and the members of that location; however, they didn't know exactly how the participation should come about, there was no project. At the time of presentation of the Educational Policy Project, the desires were met, with practically mass participation from the beginning of application of the project.

The purpose was to study the relevance of participation of the community in a shared management model. Based on existing literature, it was observed that the diverse authors studied understand a relationship of responsibility between school and community as a characteristic of successful shared management, and the school should be an open space, common to all, accessible to participation. This participation is an alternative to the problems faced by the school community as a whole.

Considering that this study is a first analysis in regard to the relationship between shared management and environmental education for a sustainable society, it was possible to verify that the interaction and integration of the school community promoted by shared management creates an ideal space so that in the school an environmental education project toward a sustainable society be implemented.

The school is enriched by the exchange of experiences and by the opportunities that are created in the context of developing partnerships and of achieving recognition within the local community and on the national scene. Moreover, the goals of improvements and refinement are more easily achieved, considering that the actions implemented benefit not only the educational institution but return to the members of that location.

The community should be motivated to have a proactive stance, leaving a reactive, nonparticipative and obsolete profile behind for the educational needs of today's youth. Parents should seek involvement in the school in a spontaneous way and, for that to occur, they should find a school which always welcomes them and is accessible for the debates that may be necessary.

The extent to which the community seeks out the school serves as a thermometer, a way for the manager to measure how his/her management is proceeding and, in a timely manner, correct the issues or items that may be in discord with the pedagogical project assumed. Hearing the community is the main factor for shared management to work, for that is the way results will be felt and evaluated, just as proposed objectives will be renewed and actions to be carried out will be directed.

The manager occupies the position of school director, but should manage not only that. In a shared management model, the manager is more a mediator than one who holds power; he/she must seek out projects and means of interaction that facilitate the growth of all those who are part of the school community.

In a shared management model, the power for deciding the path of the school does not belong to a single agent; responsibilities and obligations are taken on by all: parents, managers, teachers, students and employees. This power appears in diverse forms and may arise at various times, whether in a social activity, a joint community effort, a parentteacher meeting, a volunteer service or an informal conversation.

The educational environment only contributes to the transformation that brings about a sustainable society if it is critical and reforming. That makes it necessary to create new teaching practices within the school that promote respect for the environment and for others, understanding others as all those that make up the social space of which the 
individual is part. Thus, the relationship between environmental education and a sustainable society, and education itself as a whole, must be treated as a window that opens to knowledge, and not as an instrument that places the student in a position of being held back or controlled. Such inferences establish shared management as the guiding element of environmental education for a sustainable society since, in pedagogical practice and in school routine, shared management introduces inclusive and reflexive mechanisms where all people (students, teachers, members of school administration, service workers, family and local community) create a space for construction and reconstruction of a sustainable society.

Thus, we consider that in the school which is the object of this case study, shared management is the most adequate management model so that environmental education occurs as an element that promotes a sustainable society. Through the instruments that the school uses in shared management, there is the interaction of all the members of the school community, increasing motivation and the efficiency of the projects developed by the school. Environmental awareness and knowledge and activity directed to environmental preservation are thereby spread and they reach a greater number of individuals, attaining the ideal of a sustainable society.

\section{References}

BRASIL. Decreto n. 4.281/2002. In: Legislação de direito ambiental. 2. ed. São Paulo: Saraiva.

BRASIL. Lei n. 9.795/1999 (2009). In: Legislação de direito ambiental. 2. ed. São Paulo: Saraiva.

COSTA, Eliezer Arantes da. (2007). In: Gestão Estratégica: da empresa que temos para a empresa que queremos. 2. Ed., São Paulo: Saraiva.

DRUCKER, P. F. Uma era de descontinuidade. Rio de Janeiro: Zahar, 1975.

ESCOLA DE ENSINO FUNDAMENTAL NOSSA SENHORA DE FÁTIMA. Retrieved February 15, 2011, from http://cefnsf.blogspot.com/2009/08/planaltina-150-anos.html

HORA, Dinair Leal da. (1994). Gestão democrática na escola: artes e ofícios da participação coletiva. 15 ed., São Paulo: Papirus. (Coleção Magistério: Formação e Trabalho Pedagógico).

IDEB. Retrieved November 20, 2011 from http://ideb.inep.gov.br.

INSTITUTO NACIONAL DE ESTUDOS E PESQUISA EDUCACIONAIS ANÍSIO TEIXEIRA. Results of the IBEB 2005 to 2009. Brasília, 2006. Retrieved June 10, 2010 from www.inep.gov.br.

LEFF, Enrique (2001). Educação ambiental e desenvolvimento sustentável. In: Saber ambiental: sustentabilidade, racionalidade, complexidade, poder. 2. ed. Rio de Janeiro: Vozes.

Saber ambiental: do conhecimento interdisciplinar ao diálogo de saberes (2002). In: Epistemologia Ambiental. 2. ed. São Paulo: Cortez.

LÜCK, H. A gestão participativa na escola. 5. ed. (2009) - Petrópolis, RJ: Vozes. Série: Cadernos de Gestão.

LÜCK, H; FREITAS, K. S. de; GIRLING, R; KEITH, S. (2010). A escola participativa: o trabalho do gestor escolar. 8. ed. Petrópolis, Rio de Janeiro: Vozes.

MINISTÉRIO DA EDUCAÇÃO E CULTURA Apresenta textos e dados sobre a educação no país. Retrieved February 10, 2011 from http://www.mct.gov.br.

PENIN, S. T. S; VIEIRA, S. L. Refletindo sobre a função social da escola (2002). In: VIEIRA, S. Lerche (Ogs.). Gestão da escola - desafios a enfrentar. Rio de Janeiro: DP\&A, 13 - 43.

SACHS, Ignacy. Estratégias de transição para o século XXI. In: Para pensar o desenvolvimento sustentável. Original article: Nature and Resources, UNESCO, vol. 298, n. 1, 1992. Original title "Transition strategies for the 21st Century".

SANTOS, Clóvis Roberto dos. A gestão educacional e escolar para a modernidade. São Paulo: Cengage Learning, 2008. 
SOARES, Swamy de Paula Lima. (2008). Educação, desenvolvimento sustentável e escola do campo. Retrieved September 23 , 2012 from http://www.ufpe.br/cead/estudosepesquisa/textos/artigos_vol_2.pdf.

WELLER, Wivian; PFAFF, Nicolle (org.) (2005).Década da Educação das Nações Unidas para um Desenvolvimento Sustentável, 2005-2014: documento final do esquema internacional de implementação. - Brasília : UNESCO. 